\title{
Framing the Archives as Evidence: A Study of Correspondence Documenting the Place of Australia's Original High Court in a New Commonwealth Polity
}

Susan Priest

History in itself is fascinating, being the story of the human condition and the emergence of our species to what we hope is, and will be, a higher plane of peace and security, economic equity and respect for fundamental rights. History has an important component. That is why a life in law can never be far from history. ${ }^{1}$

When the Court sat at Noon on Saturday 29 ${ }^{\text {th }}$ April, it was announced from the Bench that circumstances had arisen which left us no alternative but to postpone the sittings of the Court appointed to be held in Melbourne on the following Tuesday ( $2^{\text {nd }}$ May) ... We did not resort to this means until the position had become intolerable. ${ }^{2}$

1 Michael Kirby, 'Is Legal History Now Ancient History?' (Speech delivered at Geoffrey Bolton Lecture, Government House Perth, 20 October 2008) 42.

2 Statement by S Griffith, 23 May 1905, regarding the court's decision to adjourn proceedings on 2 May 1905, National Library of Australia (NLA): Symon Papers MS 1736/11/865-6. 


\section{Introduction}

In early May 1905, after an increasingly acrimonious and lengthy disagreement fought out through frequent exchanges of correspondence ${ }^{3}$ between the then Leader of the Senate and fourth Federal AttorneyGeneral of the Reid-McLean Ministry, Josiah Symon, and the Justices of the original Australian High Court-Chief Justice Samuel Griffith and Justices Edmund Barton and Richard O'Connor-the High Court reached a monumental decision. The court decided that proceedings scheduled for hearing in Melbourne on 2 May were to be adjourned and went 'on strike'. ${ }^{4}$

This momentous act has since been regarded as the newly created court's final protest against Attorney-General Symon and his ultimately unsuccessful attempts, throughout the course of the previous nine months,${ }^{5}$ to interfere with the court's itinerant sitting patterns, ${ }^{6}$ including the curtailing of its travelling expenses, associated accommodation costs and the provision of staff to run the court. ${ }^{7}$ In its immediate aftermath, the decision of the bench made newspaper headlines Australia-wide. ${ }^{8}$

Approximately two months later, in early July 1905, George Houston Reid resigned as Australia's fourth Prime Minister, and Isaac Isaacs succeeded Josiah Symon as Australia's new Attorney-General under Alfred

3 Additional references to specific written communications relevant to this discourse are identified in the footnotes that follow.

4 Letter from J Symon to G Reid, 22 May 1905, NLA: Symon Papers MS 1736/11/591. In this letter, it is Symon who refers to the court's actions as a 'strike'.

5 Symon sent a telegram to his wife in South Australia informing her of his appointment to the Reid-McLean Ministry. See Telegram from J Symon to E Symon, 18 August 1904, NLA: Symon Papers MS 1736/11/23. Hence, the timeline of August 1904 until July 1905, as suggested in the title of this chapter.

6 Section 12 of the Judiciary Act 1903 (Cth) states, 'Sittings of the High Court shall be held from time to time as may be required as the principal seat of the Court and at each place at which there is a District Registry'.

7 For a more detailed account of the circumstances of this event, see Susan Priest, 'Australia's early High Court, the fourth Commonwealth Attorney-General and the "Strike of 1905" in Paul Brand and Joshua Getzler (eds), Judges and Judging in the History for the Common Law and Civil Law from Antiquity to Modern Times (Cambridge University Press, 2012) 292-305; Susan Priest, 'Archives, The Australian High Court, and the "Strike of 1905" (2013) 32(2) The University of Queensland Law Journal 253.

8 'Melbourne, Another High Court Difficulty', The Brisbane Courier (Brisbane), 2 May 1905, 7; 'Federal High Court Crisis Over Expenses', The Age (Melbourne), 4 May 1905, 4; 'The High Court Fixing The Judges Expenses', The Argus (Melbourne), 3 May 1905, 5; 'Is The High Court On Strike?' The Advertiser (Adelaide), 4 May 1905, 5. 
Deakin's leadership.' Isaacs promptly turned his attention to 'close the correspondence on the various subjects which [had] been under discussion between the Justices of the High Court and the Attorney-General [Symon] during the last few months'. ${ }^{10}$

Throughout July and August 1905, Attorney-General Isaacs offered what the court considered to be 'a satisfactory and ... permanent solution [to] the matters in question'. ${ }^{11}$ As suddenly as the dispute regarding the running expenses of the court had begun, the provisions put in place by the recently formed Deakin Government brought the disagreement to an end. ${ }^{12}$ The government ensured that the High Court would continue its practice of visiting state capitals and that all associated travelling expenses would be paid. Lastly, it was also deemed that there would be no changes to the personnel required to run the court to ensure that the interests of the community would [continue to] be served'. ${ }^{13}$

On the world stage, it may no longer be unusual for the judiciary to take industrial action, particularly over wages and conditions. ${ }^{14}$ However, to this day, the decision made by Chief Justice Samuel Griffith to adjourn court proceedings in May 1905 remains unique in the history of the Australian High Court.

It was a spirited act by Chief Justice Samuel Griffith on behalf of the original High Court in an emerging Commonwealth polity that made a lasting contribution towards permanently shaping the place and role of judicial autonomy at the apex of Australias judiciary. It also assisted in establishing what would become the contemporary day-to-day operations of the court itself. These, in an adapted form, remain to this day. As former Justice Michael Kirby reminded us in his 2001 reflections on law at the century's end:

9 JA La Nauze, Alfred Deakin: A Biography (Melbourne University Press, 1965) 398. This was Alfred Deakin's second time as Australia’s Prime Minister. See also R Norris, Deakin, Alfred (1856-1919) (1981) National Centre of Biography <http://adb.anu.edu.au/biography/deakin-alfred-5927/text10099>.

10 Letter from I Isaacs to S Griffith, 22 August 1905, NLA: Symon Papers MS 1736/11/868.

11 Ibid.

12 Ibid.

13 Ibid.

14 George Winterton, Judicial Remuneration in Australia (Australian Institute of Judicial Administration Incorporated, 1995), 1-2; Uma Sudhir, 'Telangana Judges On Strike Over Appointments Return To Work', NDTV (online), 6 July $2016<$ http://www.ndtv.com/telangananews/telangana-judges-on-strike-over-appointments-return-to-work-1428671>. 
Some features of the sittings of the High Court of Australia have remained the same. In June, as in Chief Justice Griffith's days, we return to his beloved Brisbane. In August, the Court travels to Adelaide for a week. In October, it is Perth. Chief Justice Barwick, a keen yachtsman, always attempted to visit Hobart for the Regatta Week in March. Now, the Court only travels to Hobart if business permits; and this is comparatively rare. On the establishment of the seat of Court in Canberra, Chief Justice Barwick attempted to terminate circuits to the outlying cities. This was resisted by the then Justices. Although views differ, most consider (as I do) that it is important for the Court to maintain the circuits. They provide an essential link between the serving Justices and the legal profession and litigants in the outlying States. ${ }^{15}$

Finally, the key individuals involved in these fractious written exchanges had a keen sense of rivalry to protect. ${ }^{16}$ Each had been involved untiringly, but by no means in accord, in the National Convention Debates of the 1890s, shaping line by line the Bill that would become Australia's Constitution, ${ }^{17}$ including the judiciary clauses of Chapter III. ${ }^{18}$

Therefore, it ought not be too surprising that in his position as the Attorney-General, Symon's intrusion into the running of the High Court was done under the belief that 'control over its non-judicial action ... and expenditure ... [came] ... within ... the sphere of [his role as] the Executive ${ }^{19}$ — a stance also met with marked resistance by the Chief Justice. Samuel Griffith, with equal resolve, believed it was not for the 'executive ... to instruct the Judiciary, or to intimate either approval or disapproval of their action' ${ }^{20}$ and, by insisting that the independence of the judiciary be protected, ensured that no easy or immediate solution to the conflict would be forthcoming. Nonetheless, as the preceding paragraphs have already revealed, the triumph of what remains a lasting legacy ultimately belonged to the Chief Justice.

15 Michael Kirby, 'Law at Century's End-A Millennial View from the High Court of Australia' (2001) 1(1) Macquarie Law Journal 1, 8.

16 WG McMinn, 'The High Court Imbroglio and the Fall of the Reid-McLean Government' (1978) 64(1) Journal of the Royal Australian Historical Society 14, 84-5.

17 Josiah Symon was greatly offended by Samuel Griffith's criticism of the judiciary clauses drafted when he chaired the Judiciary Committee in 1897; see John Williams, The Australian Constitution: A Documentary History (Melbourne University Press, 2005) 614-5.

18 Ibid.

19 Letter from J Symon to S Griffith, 31 January 1905, NLA: Symon Papers MS 1736/11/852.

20 Letter from S Griffith to J Symon, 21 January 1905, NLA: Symon Papers MS 1736/11/852. 
However, for the remainder of this chapter, the focus is less on the details of this intriguing narrative, and instead, provides a twofold response to a question regarding methodology. Namely, how or in what way has the extraordinary story of this jurisprudential narrative been shaped by the evidence that remains in existing archival materials?

First, my analysis will provide a brief discussion of the impact made by a series of key preserved court and departmental letters known as the 'official correspondence ${ }^{21}$ in shaping this curious tale. Then, second, a series of observations will be presented to understand something about the nature of the sway of an alternative history-as revealed through the personal correspondence exchanged between then Parliamentarian Alfred Deakin $^{22}$ and the High Court Justices throughout the dispute.

From the perspective of the author, as a researcher immersed over long periods of time in extensive hybrid collections of manuscripts ${ }^{23}$ held by the National Library of Australia, ${ }^{24}$ the National Archives of Australia ${ }^{25}$ and the State Library of South Australia, ${ }^{26}$ it is suggested that perhaps the question of methodology can be postured more colloquially. In summary, throughout the course of this intensive research process, where, in this

21 Prime Minister George Reid was perhaps the first to describe the correspondence this way. See Telegram from G Reid to J Symon, 24 May 1905, NLA: Symon Papers MS 1736/11/595. This correspondence later became known as the Correspondence Between Attorneys-General and the Justices of the High Court RE Sitting Places and Expenses of the Court, NLA: Symon Papers MS 176/11/84968. This Senate publication consists of 89 letters in total, with the first correspondence commencing 29 July 1904 and the last dated 23 August 1905.

22 Alfred Deakin was the recipient of the personal correspondence from the original High Court at a time when he had refused to join the Reid-McLean Government and, in his words, believed 'he could assist the Government more by sitting behind it than becoming a member of it'; see Commonwealth, Parliamentary Debates, House of Representatives, 29 June 1905, 81 (A McLean, Minister for Trade and Customs).

23 The use of the term 'hybrid' indicates that the collections are a combination of institutional and personal papers. See the earlier work of Paul Dalgleish, 'The Appraisal of Personal Records of Members of Parliament in Theory and Practice' (1996) 24(1) Archives and Manuscripts 86, 87.

24 The initial use of these archives was for my PhD; Susan Priest, A Commonwealth AttorneyGeneral and the early High Court, August 1904 - July 1905 (PhD Thesis, Macquarie University, 2011). These include the AJ Buchanan Papers, 'The Prime Ministers of Australia', 1940, MS 3034, vol 1; the H Campbell-Jones Papers, 'The Cabinet of Captains: The Romance of Australia's First Federal Parliament', 1935, MS 8905, Folders 1-3; the LF Crisp Papers, 1917-1984, MS 5243; the A Deakin Papers, 1804-1973, MS 1540, Series 14, 16; the JA la Nauze Papers, 1888-1984, MS 5248, Folders 115, 323, 328 and 375. Permission granted by L Cleland to view Folder 323 and the JH Symon papers, 1820-1959, MS 1736, Series 3, 6, 7, 8, 9, 11, 14, 29.

25 National Archives of Australia: A6006 1905/8/7.

26 The State Library of South Australia, Private record Group, 249, 'The Symon Family 1897-1976'. 
instance, most of the federal archival documents appear largely intact and readily accessible to the researcher, what can be gleaned from the historical evidence as it emerged from 'reading other people's mail' ${ }^{27}$ written more than 100 years ago?

\section{The Archives as Evidence I: Official Correspondence}

The letters extending over a period of twelve months, were many, in some cases very long, and at times pointed..$^{28}$

The use of letters by scholars for research purposes is by no means a 'new pedagogical phenomenon', ${ }^{29}$ and their enduring or lasting sociohistorical value to the work of historians, legal historians biographers and writers alike remains well-documented. ${ }^{30}$

Further, even though it is readily conceded in the $21^{\text {st }}$ century that the use of mobile phones, emails and other types of social media exchanges are quicker and may typically be regarded as a 'new form of letter writing', ${ }^{31}$ written communications, including letters of state, remain of significant research value as a 'remarkable protean form of writing'. ${ }^{32}$

27 Maryanne Dever, 'Reading Other People's Mail' (1996) 24(1) Archives and Manuscripts 116, 116-29; see also her earlier lecture Maryanne Dever, 'Reading Other Peoples Mail' (Speech delivered at the National Library of Australia, 25 October 1995) <https://www.nla.gov.au/maryanne-dever/ reading-other-peoples-mail>.

28 'The High Court. Circuits and Travelling Expenses. Interesting Correspondence', The Argus (Melbourne), 25 August 1905, NLA: Symon Papers MS 1736/3/120.

29 R Holmes, 'The Past Has a Great Future' (2008) (November) Australian Book Review 26, 27.

30 J Kent, 'Creating Lives: The Role of the State Library of NSW in the Creative Process of Biography', (2002) (August) LASIE 83, 83-90; Maryanne Dever, 'A Friendship that is Grown on Paper: Reflections on Editing Majorie Bernard's Letters to Nettie Palmer' (2005) 19(1) Antipodes 13, 13-19; John Thompson, 'Some Australian Letters of Love and Friendship' (1998) 8(10) National Library of Australia News 11, 11-15; Dever (1996), above n 27; Adrian Cunningham, 'The Mysterious Outside Reader' (1996) 24(1) Archives and Manuscripts 130, 130-44; Miriam Estensen, The Letters of George and Elizabeth Bass (Allen \& Unwin, 2009); H Anna Suh (ed), Van Gogh's Letters (Black Dog \& Leventhal, 2010).

31 Jennifer Moran, 'Potency of the Pen' (2008) 18(12) National Library of Australia News 7, 7.

32 Thompson, above n 30, 11-15. As a recent example, see Michela McGuire and Marieke Hardy, Signed, Sealed, Delivered: A Collection from Women of Letters (Viking Press, 2016). 


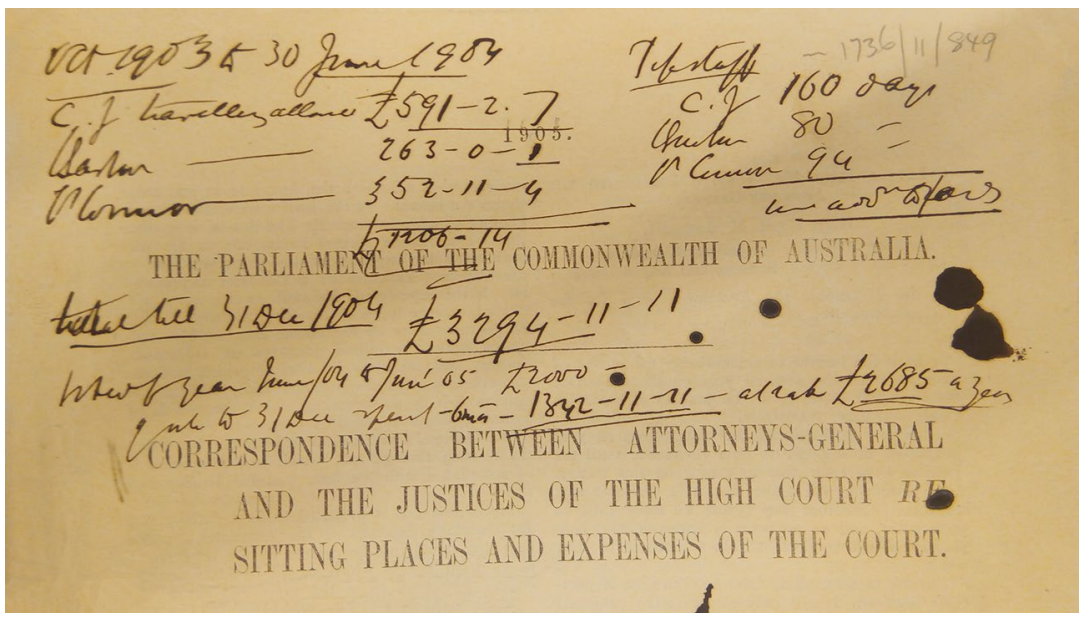

Figure 1: Correspondence between Attorneys-General and the Justices of the High Court re sitting places and expenses of the court.

Source: NLA Symon Papers MS 176/11/849.

Even if letter writing might be regarded as a diminishing art, correspondence is a permanent manifestation of writing that permits the reader to understand something about the ways in which the quality and character of individuals of the past, who were unwilling to converse with each other face-to-face, used the privacy of the letter to express themselves. ${ }^{33}$ John Wishart documented these ideas in 1921 when he stated:

Letters ... reveal the inner history of great national events of the time in which they were written ... names to most readers, become real persons to those who have read their letters ... The little incidents of every-day life ... give an insight into the thoughts and actions of our forefathers such as no amount of description can provide. To read such letters is to enter into the life of days gone by, to accompany the writers in their business ... to look at the world as they knew it through their eyes. ${ }^{34}$

While such observations readily confirm the merits, for research purposes, of examining correspondence for what its close association with both their writers and history will reveal to a reader, the same commentaries go further in their contribution to the focus of this chapter. 
These sources verify that the 'high-water $\operatorname{mark}^{35}$ of letter writing encompassed specifically the time of the dispute between Attorney-General Symon and the original Australian High Court. ${ }^{36}$ They also reveal that the common notion of correctness, or practised conventions, dominated letter writing at this time to an extent unknown before or since. ${ }^{37}$

In a telegram sent from then Prime Minister George Reid to AttorneyGeneral Symon dated 24 May 1905, ${ }^{38}$ the Prime Minister suggested that Cabinet may have discussed the likelihood of publishing these letters with the intent of showing 'that there were faults on both sides ${ }^{39}$ of the disagreement. His prediction, in the end, ultimately proved to be correct.

The collection of 89 letters of state that became known as the 'official correspondence', ${ }^{40}$ exchanged between the Attorney-General's Department and the Justices of the High Court between the months of July 1904 and early August 1905, presented in foolscap typeset, ${ }^{41}$ appear to conform to the practised conventions as business letters of the day required. ${ }^{42}$

They were frequently answered similarly to the one received and promptly answered. ${ }^{43}$ Each member of the High Court, when writing to AttorneyGeneral Symon or vice versa, addressed each other as business letters of the day required. ${ }^{44}$ They often used 'My dear Sir ${ }^{\text {'45 }}$ or 'Sir' ${ }^{26}$ and ended with 'Yours faithfully', ${ }^{47}$ 'I have the honour to be ... Your obedient Servant', ${ }^{48}$ or more commonly, 'We have, \&c.', ${ }^{49}$ or 'I have \&c. . ${ }^{50}$

35 Ibid. This high-water mark is purported to have ended around 1918.

36 Ibid.

37 Ibid.

38 Telegram from G Reid to J Symon, 24 May 1905, NLA: Symon Papers MS 1736/11/595.

39 WG McMinn, George Reid (Melbourne University Press, 1989) 218.

40 Telegram from G Reid to J Symon, 24 May 1905, NLA: Symon Papers MS 1736/11/595.

41 Correspondence Between Attorneys-General and the Justices of the High Court RE Sitting Places and Expenses of the Court, NLA: Symon Papers MS 176/11/849-68.

42 Mrs Erskine (full name unknown), Etiquette in Australia (William Brooks \& Co., 1911) 71 indicates that business letters needed to be answered promptly and in the same form as the one received. 43 Above $\mathrm{n}$ 41. The dates on this correspondence indicate replies to letters received ranged from the same day to only several days apart.

44 Ibid.

45 Ibid.

46 Ibid.

47 Ibid.

48 Ibid.

49 Ibid.

50 Ibid. 
To contemporary eyes, such expressions of politeness appear to be at odds with the contents of the letters that generally seem to remain aloof, uncompromising, acerbic and, at times, lengthy and rather repetitive.

Described by other scholars who examined these letters of state several decades ago, the correspondence on Attorney-General Symon's part, according to one, was written with 'fiendish ingenuity and sinister powers' ${ }^{51}$ According to others, the letters were 'marked on both sides by suppressed fury, and deadly icy courtesy', ${ }^{52}$ being eloquent, but not overly elaborate in style and frequently long; ${ }^{53}$ descriptions perhaps that ought not to be too startling.

Contemporaries of Attorney-General Symon, for instance, have suggested that he was well-recognised for his 'lucid and pungent' ${ }^{\text {'54 }}$ writing style, which, at the time of his death in 1934, was paralleled with his eminence, ${ }^{55}$ not only for his work as a lawyer but also with his contributions as a legislator, a lecturer and an author. ${ }^{56}$

Similarly, AD Graham, a barrister who claimed to have known Chief Justice Samuel Griffith for 'some years', ${ }^{57}$ reflected on Griffith as a writer. ${ }^{58}$ He stated that the Chief Justice not only 'wrote an excellent letter', ${ }^{59}$ but 'had ... a complete knowledge of the etiquette of official correspondence, and knew exactly the intricacies of the appropriate addresses and signatures of letters passing to and fro in Government departments ${ }^{6}{ }^{60}$

However, in seeking alternative ways to interpret the contents of the formal correspondence, insights are readily documented that see beyond a narrative merely concerning an unseemly and prolonged clash of words.

51 La Nauze, above n 9, 383.

52 Gavin Souter, Lion and Kangaroo; The Initiation of Australia (Text Publishing, 2000) 110.

53 McMinn, above n 16, 14, 29.

54 JJ Pascoe (ed), History of Adelaide and Vicinity: With a General Sketch of the Province of South Australia and Biographies of Representative Men (Hussey and Gillingham, 1901) 374.

55 'Death of Sir Josiah Symon', The Advertiser (Adelaide), 30 March 1934, 7.

56 Ibid.

57 Douglas Graham, The Life of the Right Honourable Sir Samuel Walker Griffith, GCMG PC

(Powells and Pughs, 1939) 2.

58 Ibid 88-93.

59 Ibid 92.

60 Ibid 93. 
On 25 August 1905, the Melbourne $A g e^{61}$ suggested that its reading public consider, as identified in the introductory paragraphs of this chapter, that this unique event in Australian legal history not only be regarded as a petty argument between the executive and the judiciary but also as an argument involving questions of principle:

The epistolary altercation ... of a long and bitter controversy, revolving sometimes round petty matters ... sometimes round large questions of principle. Sir Josiah Symon seems to have irritated the judges and the judges ... appear to have snubbed the then Attorney-General on the slightest provocation. The spectacle presented by the letters is an unyielding one ... It closes with a letter written by the present AttorneyGeneral, placing the whole of the matters in dispute on a basis which has given satisfaction to the judges, and at the same time scale of economies. ${ }^{62}$

Moving into the $21^{\text {st }}$ century, in One Hundred Years of the High Court of Australia, ${ }^{63} \mathrm{JM}$ Williams clarified the notion of principle further. He suggested that any narrative concerning the High Court brings with it 'an important reminder' '64 that it is not an 'anonymous institution', ${ }^{65}$ but is staffed by personnel 'who bring character, and in some cases drama, to the work of the Court' ${ }^{6}{ }^{6}$ None more so perhaps than the original High Court tasked with establishing the 'Court in the Australian hierarchy ... [and] winning $\ldots$ the respect of the local profession and judiciary'. ${ }^{67}$

Chief Justice Murray Gleeson, writing extrajudicially in 2007, also underscored the significance of the relationship between personalities and principles. He indicated that no matter how strong the personal opinions may have been between those involved in Australia's federal movement, it remains necessary to look beyond their robust exchanges and examine carefully the context in which these exchanges occurred. ${ }^{68}$ In part, the former Chief Justice observed:

61 'High Court Judges', The Age (Melbourne) 25 August 1905, NLA: Symon Papers MS 1736/3/120; see also 'The High Court. Circuits and Travelling Expenses. Interesting Correspondence', The Argus (Melbourne) 25 August 1905, NLA: Symon Papers MS 1736/3/120 and the 'High Court Official Correspondence. Some Plain Speaking. The Justices' Views Adopted', The Advertiser (Adelaide), 24 August 1905, 5, who cautioned its readers that the correspondence would take two-and-a-half hours to read.

62 Ibid.

63 John Williams, One Hundred Years of the High Court of Australia (Menzies Centre for Australian Studies, 2003).

64 Ibid 30.

65 Ibid.

66 Ibid.

67 Ibid 31.

68 Murray Gleeson, 'The Constitutional Decisions of the Founding Fathers' (2007) 9 University of Notre Dame Australia Law Review 1. 
In interpreting a legal instrument, including a Constitution, what finally matters is the meaning of what the instrument says. The task is to construe the text. The authors of the text employed particular language, and it is the effect of that language, [and] not their beliefs about that effect, that is legally binding. ${ }^{69}$

Most recently, acknowledging that the story of the strike has been 'been told a number of times ... [and] ... in a variety of ways' ${ }^{70}$ Justice Stephen Gageler described the unfolding tensions as 'a quarrel which wound its way "through a labyrinth of spite and petty vituperation on both sides", but "originated in a noble vision" and which bore on "an important principle"..$^{71}$ :

Griffith's triumph and Symon's ignominy cannot gainsay the mixture of pettiness and principle which fuelled the actions and reactions of each. To the extent the principle can be separated from the pettiness, their battle was about the boundaries of judicial independence and about the balance between judicial independence and judicial accountability. And to that extent, recalling their battle has some enduring significance. ${ }^{72}$

Lastly, if we return to the archives of original letters, Attorney-General Josiah Symon writing to Alfred Deakin in June 1905 echoed similar views. He was 'grateful'73 for Deakin's remarks 'as to our differences upon my purposes in regards to the High Court ${ }^{74}$ and, despite all that had occurred, hoped that it would have little impact on their collegiality. In anticipation of any future communications between them, he also hoped that 'our jurat intercourse ... shall not be affected' ${ }^{75}$

Finally, if any types of administrative oversights or errors occurred during the compilation of the letters that became known as the official correspondence, existing archival evidence on these issues remains silent. Attorney-General Symon did leave a legacy in this regard and specifically noted on his copy of the published volume of the official correspondence that one letter to the court, dated 16 February $1905,{ }^{76}$ was missing but subsequently located elsewhere. ${ }^{77}$

69 Ibid 17.

70 Stephen Gageler, 'When the High Court Went on Strike' (2017) 40(3) Melbourne University

Law Review 1098, 1099.

71 Ibid 1101, citing DI Wright, 'Sir Josiah Symon, Federation and the High Court' (1978) 64

Journal of the Royal Australian Historical Society 73.

72 Ibid 1130.

73 Letter from J Symon to A Deakin, 25 June 1905, NLA: Deakin Papers 1540/16/414.

74 Ibid.

75 Ibid.

76 NLA Symon Papers MS 1736/11/849-68.

77 Letter from J Symon to S Griffith, 16 February 1905, NLA: Symon Papers MS 1736/11/728. 
Even so, as a researcher having full access to official court archives, this discovery left an impression that additional archives remain beyond reach or are yet to be found. As Maud Bailey lamented in AS Byatt's Possession, 'you know if you read the collected letters of any writer ... there is always "something ... biographers don't have access to, the real thing, the crucial thing ... There are always letters that were destroyed. The letters, usually"' ${ }^{78}$

\section{The Archives as Evidence II: Personal Correspondence, Letters to Alfred Deakin}

It is impossible to create a federation without having divisions and distributions of powers, without having different organs of government possibly in conflict. Therefore from the necessities of federation, and as one of the inevitable consequences from which we cannot escape, we find ourselves in a new situation of comparative peril and serious responsibility. Hence we must necessarily have an Australian court for the determination of principles which shall be common to the whole Continent, based upon a survey of the requirements of the whole people. If the legislative and executive powers of the States, the Commonwealth, and the Imperial Governments are to be judicially restrained each to its own sphere we have before us a difficult task. ${ }^{79}$

Alfred Deakin was not a gregarious person ... His friendships were few, and almost none came from his political life, Barton and O'Connor being the exceptions in that they were his personal friends as well as political allies. ${ }^{80}$

78 Catherine Burgass, AS Byatt's Possession: A Readers Guide (The Continuum International Publishing Group Ltd, 2002) 45.

79 NLA Deakin Papers MS 1540/14/1038 9.

$80 \mathrm{Al}$ Gabay, 'Alfred Deakin and his Friends' in David Headon and John Williams (eds), Makers of Miracles The Cast of the Federation Story (Melbourne University Press, 2000) 82. 


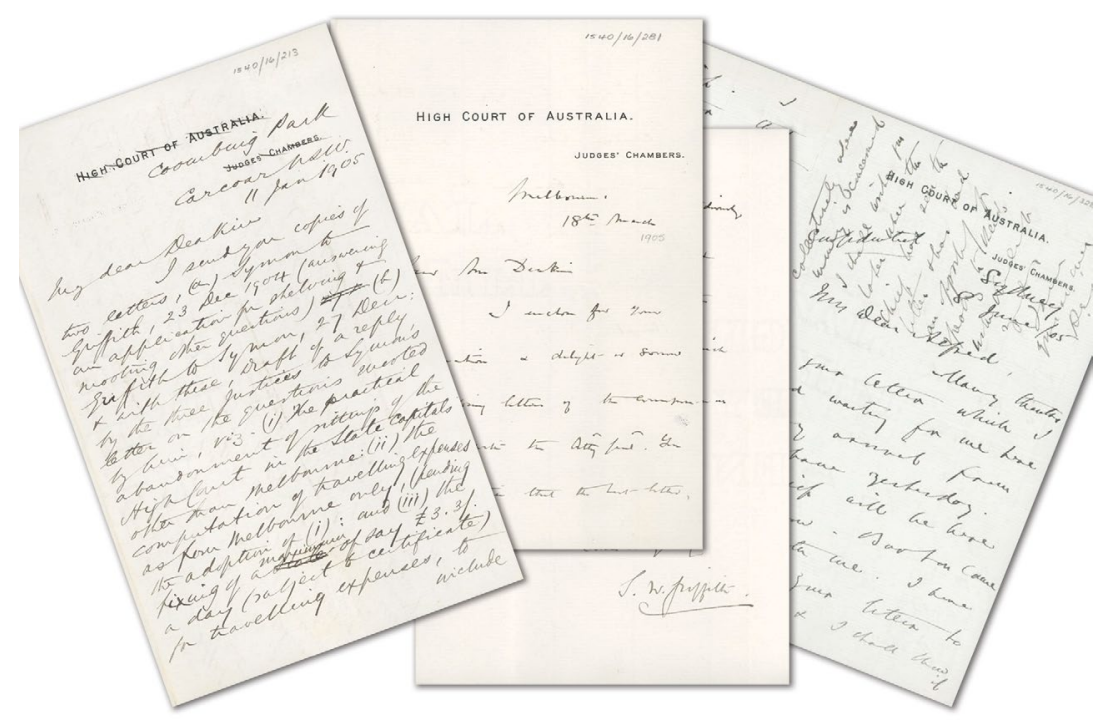

Figure 2: Correspondence from each of the High Court members to Alfred Deakin.

Source: NLA Deakin Papers 1840/16/213; 1840/16/281; 1840/16/328.

The significance of the use of court and departmental letters as archival evidence to the researcher cannot be underestimated it would seem. However, this historical importance for research purposes is further magnified when discussing the place of personal letter writing in research; the historical value of those communications 'passed on ... in a confidential relationship'. ${ }^{81}$

In a series of incomplete letters that remain as part of the Deakin papers, ${ }^{82}$ a brief but manifestly personal understanding is revealed into how each of the judges felt about the nature of their formal frequent written exchanges with Attorney-General Symon. They provide a reader with an immediate and compelling alternate history that can lend both originality and depth of historical analysis to the story of the judicial strike of 1905 .

The original three Justices of the High Court turned to Alfred Deakin as their 'trusted friend, the legislative father of the court and the only man who might be able to protect them by private representations, since Prime 
Minister Reid seemed unwilling or unable to intervene between them and the formidably venomous Symon'. ${ }^{83}$ This collection of letters, most frequently penned to Alfred Deakin by Justice Richard O'Connor, are incomplete because none of Deakin's original written replies are part of the Deakin collection. Nonetheless, the letters that do remain reveal the High Court bench from a different perspective; an original Federal Judiciary appalled by the personal attack of the Attorney-General and frustrated by his fierce resistance to achieve a lasting and mutually agreeable outcome to the drawn-out circumstances of the controversy.

In contrast to the official typeset correspondence, these letters are, for the main, all handwritten, extremely difficult to read and, at times, are illegible. They were exchanged during January, February, March and, more regularly, June 1905. Unlike the formal correspondence, the tone in each of the letters appears gracious and forthcoming, and they were written between individuals with complete trust and confidence in each other. $^{84}$

In stark contrast to the formalities required with official correspondence, Alfred Deakin is addressed as 'Dear A. D.', 85 'Dear Deakin' ${ }^{36}$ or 'My Dear Alfred', ${ }^{87}$ and the letters frequently conclude with 'yours as ever' ${ }^{88}$ or 'yours always' ${ }^{89}$

Through these exchanges, the congenial relationship that existed exclusively between each of the Justices is also confirmed. In one instance, the Chief Justice and Justice Barton had written separate notes to Deakin on the same page, ${ }^{00}$ and, in another, Justice Barton puts pen to paper in the full knowledge that copies of Attorney-General Symon's letters had already been sent from Justice O'Connor a few days earlier. ${ }^{11}$ Alfred Deakin was privy to the original High Court's deeply personal attitudes towards the nature of the dispute from its outset.

83 JA La Nauze, above n 9, 383.

$84 \mathrm{Al}$ Gabay, above n 80, describes Barton and O'Connor as being Deakin's 'personal friends' and 'political allies'.

85 Letter from E Barton to A Deakin, 16 February 1905, NLA Deakin Papers MS 1540/16/187.

86 Letter from E Barton to A Deakin, 26 February 1905, NLA: Deakin Papers MS 1540/16/245.

87 Letter from R O'Connor to A Deakin, 12 June 1905, NLA: Deakin Papers MS 1540/16/335.

88 Letter from R O'Connor to A Deakin, 21 June 1905, NLA: Deakin Papers MS 1540/16/389.

89 Letter from E Barton to A Deakin, 21 June 1905, NLA: Deakin Papers MS 1540/16/385.

90 Letter from S Griffith to A Deakin and letter from E Barton to A Deakin, 16 February 1905, NLA: Deakin Papers MS 1540/16/187.

91 Letter from E Barton to A Deakin, 21 June 1905, NLA: Deakin Papers MS 1540/16/385. 
On 11 January 1905, ${ }^{92}$ Justice Edmund Barton sent Alfred Deakin copies of two letters the court had received from the Attorney-General dated 23 December 1904, and the Chief Justice's response of 27 December 1904, respectively. ${ }^{93} \mathrm{He}$ also enclosed a copy of the court's draft response to Symon ${ }^{94}$ and identified the early proposals the Attorney-General had put forward to the court to address ways of curtailing its expenditure. These, in Justice Barton's words, were threefold: 'the practical abandonment of sittings of the High Court in the State capitals other than Melbourne'; ${ }^{95}$ that travelling expenses would be computed from Melbourne only; and that the judges would be paid a fixed daily rate of three guineas. ${ }^{96}$ However, the main reason for writing at this stage was to ensure that Deakin was informed of 'everything so far'. ${ }^{97}$

A month later, Justice Barton wrote again. By 16 February 1905, he had already referred to the Attorney-General's letters in earlier correspondence as being peculiarly 'insulting in tone, ${ }^{98}$ but by 26 February, AttorneyGeneral Symon's letters contained 'screeds on the subject of the abolition of the system of holding court in the District Registries. ${ }^{99}$ In addition, before the court was able to write a 'joint letter' ${ }^{100}$ in response to the latest communication from the Attorney-General, Symon was writing to them again in a manner that was 'more extraordinary and more insulting than anything that had gone before'. ${ }^{101}$ Barton once again enclosed copies of the letters to give Deakin a 'complete grasp of the matter', ${ }^{102}$ but on this occasion, his correspondence concluded with an individual request for assistance. 'If you find what seems to you as a solution please let me have it always ... yours sincerely Edmund Barton'. ${ }^{103}$

\footnotetext{
92 Letter from E Barton to A Deakin, 11 January 1905, NLA: Deakin Papers MS 1540/16/ 213.

93 NLA Symon Papers MS 1736/11/850-1 are the original references for Symon's letters.

94 Above $\mathrm{n} 92$.

95 Ibid.

96 Ibid.

97 Ibid.

98 Letter from E Barton to A Deakin, 16 February 1905, NLA: Deakin Papers MS 1540/16/187.

99 Letter from E Barton to A Deakin, 26 February 1905, NLA: Deakin Papers MS 1540/16/245.

100 Ibid.

101 Ibid.

102 Ibid.

103 Ibid.
} 
Deakin's response to the circumstances, according to JA La Nauze, was one of disbelief. The Attorney-General's letters had 'shocked' ${ }^{104}$ him and left him 'humiliated'. ${ }^{105}$ He thought that Symon had an 'immense advantage' 106 over the High Court because he treated the judges as they were 'constitutionally supposed to be' ${ }^{107}$ treated 'while all the time [Symon] is throwing mud like a larrikin at you and exercising the petty tyranny that his position allows'. ${ }^{108}$ He encouraged the Justices to destroy the correspondence for both 'the sake of the Commonwealth and the High Court'. ${ }^{109}$

Other revelations from the judges throughout the next four months followed. Chief Justice Griffith sent copies of Symon's latest letters to the bench to Deakin in a brief note on 18 March 1905, enclosing them for Deakin's 'delight or sorrow'. ${ }^{110}$

A large gap in the archival materials exists until Justice O'Connor again wrote to Deakin in early June. ${ }^{111}$ By that time, the court's decision to adjourn proceedings and go on strike had already taken place, and their reasons for doing so had already been made public. Nevertheless, Justice Richard O'Connor thought that a solution to the dispute was still possible. ${ }^{12}$

Aware that Prime Minister 'Reid ha[d] now left the matter to Symon'113 to resolve, Justice O'Connor expressed his regret that the correspondence could not be withdrawn as it was 'too late'. ${ }^{114} \mathrm{He}$ went on and rightly predicted that 'Parliament will probably demand to see' it. ${ }^{115}$

Days later, O'Connor made a rather startling revelation. Despite the misconception Attorney-General Symon might have had in thinking he would 'eventually induce us [the court] to give up opposing him', ${ }^{116}$

104 La Nauze, above n 9, 384 .

105 Ibid.

106 Ibid.

107 Ibid.

108 Ibid.

109 Ibid.

110 Letter from S Griffith to A Deakin, 18 March 1905, NLA: Deakin Papers MS 1540/16/281.

111 Letter from R O’Connor to A Deakin, 8 June 1905, NLA: Deakin Papers MS 1540/16/328.

112 Ibid.

113 Ibid.

114 Ibid.

115 Ibid.

116 Letter from R O’Connor to A Deakin, 12 June 1905, NLA: Deakin Papers MS 1540/16/335. 
O'Connor wrote about the urgency and necessity of discussing and settling the matter with the Attorney-General, especially if 'Symon himself became a member of the Court'. ${ }^{117}$ However, such an appointment occurring sometime in the future, given the manner in which the Attorney-General had behaved towards the judges, was deemed 'unlikely'118 to occur.

On 19 June, renewed written attacks from Attorney-General Symon were interpreted by Justice O'Connor as the 'absolute freehand' 119 the Attorney-General had been given by Prime Minister Reid 'to wreck as far as he can the High Court establishment as you [Deakin] and we designed it should be when we first took office'. ${ }^{120}$ Then, on the following page, O'Connor confirmed, as Symon had threatened that he would do in his 26 April 1905 letter, that 'the official telephones were disconnected [in their Sydney chambers except one] today. ${ }^{121}$

Still the optimist, Justice O'Connor's letter concluded on a positive note, looking towards an opportunity for a change to the current and untenable circumstances:

We are all curious to hear what you have to say at Ballarat-when I say 'we' I do not mean the High Court, but all Federalists and indeed all them who wish to see Parliament lift out of the slough ... into which Reid has dropped it.

I am sure you will do what you think best in the interest of the Commonwealth apart from any other considerations. ${ }^{122}$

On 21 June 1905, Edmund Barton wrote his last letter about the crisis to Alfred Deakin. ${ }^{123} \mathrm{He}$ revealed, perhaps in the most intimate terms, the impact the dispute was having upon him. In his view, it had now become 'impossible to do one's work efficiently' ${ }^{124}$ because of the disturbing nature of the contents of Symon's latest letters to the court both dated 9 June $1905 .^{125}$

117 Ibid.

118 La Nauze, above n 9, 416.

119 Letter from R O'Connor to A Deakin, 19 June 1905, NLA: Deakin Papers MS 1540/16/378.

120 Ibid.

121 Ibid; J Symon to S Griffith, 26 April 1905, NLA: Symon Papers MS 1736/11/858 is where the Attorney-General initially indicated he would change the existing arrangements with regard to the payment for telephone usage.

122 Letter from R O'Connor to A Deakin, 19 June 1905, NLA: Deakin Papers MS 1540/16/378.

123 Letter from E Barton to A Deakin, 21 June 1905, NLA: Deakin Papers MS 1540/16/385.

124 Ibid.

125 See NLA: Symon Papers MS 1736/11/860 and 861 for copies of these letters to the court. 
According to Barton, the Attorney-General in these two communications had now surmised:

his determination to pack our tipstaffs off at a few days notice and turn them adrift upon the world. Shocked as I had been at the ... venom of the war, it was natural to fear that he would resort to such a cruelty to these innocent officers for the mere purpose of satisfying his hatred of us. ${ }^{126}$

Then, he finished his letter by adding:

One feels all this bitterly. We are in every way degraded and humiliated by this unspeakable scoundrel: and if Australia offers the Judges of her one and only national Court to be treated thus she will deserve as she has not yet done the scoffs and jibes of the English speaking world. My wife wishes me to resign rather than submit to any further indignity but at least I shall wait to see whether Parliament adopts or condones, the outrage we have suffered, of which every day brings a new one in the shape of an insulting letter. ${ }^{127}$

Fortunately, for the Griffith Court, the original High Court bench would remain a united one. In addition, Justice Richard O'Connor had been right in his June 1905 prediction to Deakin. ${ }^{128}$

The controversy between the High Court and Attorney-General Symon would only be resolved by an 'appeal to Symon's successor', ${ }^{129}$ and it was. The decisions reached by the new government, as documented at the beginning of this chapter, brought the dispute to an end.

\section{The Archives as Evidence III: Concluding Notes on Methodology}

Then there are emanations from the documents themselves, which the historian sometimes exposes to the light for the first time since they were preserved. ${ }^{130}$

[T] he greatest strength of a position depends on its facts, its greatest weakness arises from its epithets. ${ }^{131}$

126 Letter from E Barton to A Deakin, 21 June 1905, NLA: Deakin Papers MS 1540/16/385.

127 Ibid.

128 Letter from R O’Connor to A Deakin, 12 June 1905, NLA: Deakin Papers MS 1540/16/335.

129 Ibid.

130 Tom Griffith, The Art of Time Travel (Black Inc., 2016) 11.

131 Telegram from G Reid to J Symon, 24 May 1905, NLA: Symon Papers MS 1736/11/595, 597. 
The notion of missing primary sources from manuscripts and records, such as the letters documenting Alfred Deakin's personal replies to the Justices of the High Court, has been described generally in secondary sources as a concept referred to as the 'fissured archive'. ${ }^{132}$ As the expression denotes, it refers to materials that survive as evidence in archival materials but ultimately remain as a part of what may have originally been their total. ${ }^{133}$

This is a useful choice of words because not only does it highlight the limitations on tasks a researcher can achieve when key documents are missing, but, as a consequence, the information when ultimately presented, as highly relevant and compelling as it may be for research purposes, has the potential to be often fragmented and rather disjointed. Again, to use a similar colloquial expression cited above, the experience of this as a researcher and writer is one of never playing with a 'full hand'. ${ }^{134}$

Instead, having to accept that in the private correspondence between Alfred Deakin and the High Court, they could only reveal discrete snippets or instances from the parties about the information they wished to convey, it made subsequent interpretations and reinterpretations for writing purposes an extremely difficult undertaking for the researcher. Particularly when trying to fill in the gaps with words that could only be representations and unable to guarantee a full comprehension or even an 'impartial review' ${ }^{135}$ of all the details enclosed in the correspondence.

This dilemma is perhaps especially relevant in 2018, where, in the age of disclosure, our sense regarding the privacy of individuals and the extent to which they will be exposed 'has been systematically eroded over the years by the public's right to know' ${ }^{136}$ Further, it was Prime Minister George Reid who predicted that under such circumstances personal motives had the potential to be 'unfairly decried', ${ }^{137}$ which remains a relevant observation even today.

132 Dever (1996), above n 27, 119.

133 Ibid.

134 Ibid.

135 HG Turner, The First Decade of the Australian Commonwealth: A Chronicle of Contemporary Politics 1901-1910 (Mason, Firth and McCutcheon, 1911) vii.

136 Dever (1996), above n 27, 117.

137 Turner, above n 135 , vii. 
Therefore, as acknowledged by writers before me who have studied other kinds of early letters written by Australian public figures, ${ }^{138}$ there is little reason to doubt that both types of correspondence referred to throughout this chapter have presented a valuable 'tangent to reflect a key moment in Australian legal history' for research and writing purposes. ${ }^{139}$ However, these observations, it is suggested, offer much more.

The contents of the archival materials, including private correspondence, have been powerful reminders of personal histories as well—supplements to a specific time in Australia's legal history by providing information, opinions and attitudes that can have a dramatic and intensely personal impact on how a very public set of circumstances in existing formal letters of state are interpreted.

In short, as this chapter sets out to demonstrate, histories have ultimately been shaped by numerous tensions, as much by what is known as what is not known. The 'absences and the subtle silences', ${ }^{140}$ which structured my reading from the archives remain and serve in the end to act as but a representative of the whole to depict a narrative as comprehensively and as systematically as those resources will allow.

As Marianne Dever wrote in 1996, in the end, reading the archival materials - in this instance, both the formal and personal correspondence pertaining to the strike of 1905 - was, from time to time, a little like:

being the proverbial eavesdropper on a telephone call, inferring from the overheard fragments of information those portions of conversation to which one is not privy. I read between the lines. But this partial and disconnected dialogue leaves me unable to clarify so many details ... I can picture but not pin down. ${ }^{141}$

Finally, it was demonstrated, particularly from the list of the early references included in the preceding pages, that a broad interest in letter writing by researchers 'with its own unique qualities of style and personal expression ${ }^{142}$ continues against all the odds to make a regular appearance on the publication list of books.

138 Thompson, above n 30, 11.

139 Ibid.

140 Ibid 12.

141 Dever (1996), above n 27, 126.

142 Thompson, above n 30, 11. 
In writing his much-acclaimed biography of Alfred Deakin, JA La Nauze revealed what has already been stated in the previous section of this chapter. Alfred Deakin wished under no circumstances for the correspondence between the High Court and then Attorney-General to ever be made public. ${ }^{143}$ However, in the same publication, La Nauze expressed his view that, if a study of the dispute were ever to be undertaken, it would provide the substance for a 'fascinating study in character'. ${ }^{144}$ Indeed, it has. Even so, the unease about the controversy and shame Alfred Deakin expressed about the realisation that the written exchanges might be made public can be put to rest.

The original Justices took a resolute position of principle. Under the leadership of Chief Justice Samuel Griffith, they established the foundations of the High Court as they thought it should and would continue: to attain 'high standards of integrity, learning, ability and industry'. ${ }^{145}$

For the former Attorney-General, Josiah Symon, the High Court affair, as it had for all individuals involved, seemed to have taken an enormous toll. In a public and rather emotive demonstration of this, Symon made an important distinction between the contributions he had made to the dual parliamentary roles he had held in the Reid-McLean Ministry. When he resigned his position as Leader of the Senate on Wednesday, 5 July 1905, he made it known to the Chamber that:

In relinquishing this position which I have been proud to hold, and whose duties I have been proud to discharge-I do not mean the official position of Attorney-General, but the position of leader of this great and august assembly - I part company from all my honourable friends here, certainly on my part, with what will always be a constraint of feeling of personal regard, and I am sure that it will be reciprocated by the goodwill of all my friends. I move-That the Senate at its rising adjourn. ${ }^{146}$

143 La Nauze, above n 9, 384.

144 Ibid 382.

145 Harry Gibbs, 'Griffith, Samuel Walker' in Tony Blackshield, Michael Coper and George Williams (eds), The Oxford Companion to the High Court of Australia (Oxford University Press, 2001) 311.

146 Commonwealth, Parliamentary Debates, Senate, 5 July 1905, 134 (JH Symon). 
In short, when combined and used as evidence, both official and personal letters both disclose and confirm that behind the historical narrative of strong or robust opinions of the Federation Fathers, ${ }^{147}$ a constitutional battle testing the parameters of the separation of powers doctrine to maintain the well-ordered dignity of the High Court was far greater.

The resolute personality of Australia's founding Chief Justice of the High Court, Samuel Griffith, displayed a determination to establish the independence of the court from its beginning, including its sitting patterns and the staff required to ensure its operation at the apex of the judiciary in an emerging Commonwealth polity.

However, the final words regarding methodology belong to Charles Darwin. In a completely different context in his writing in the Descent of Man, he stated that 'we are not here concerned with hopes and fears, only with truth as far as our reason allows us to discover it'. ${ }^{148}$ 
This text is taken from The Court as Archive, edited by Ann Genovese, Trish Luker and Kim Rubenstein, published 2019 by ANU Press, The Australian National University, Canberra, Australia. doi.org/10.22459/CA.2019.05 